\title{
Foreign Acquisitions by UK Limited Companies: Short and Long-Run Performance
}

\author{
Paper Number: 04/01
}

\author{
Alan Gregory* \\ Xfi Centre for Finance \& Investment \\ Steve McCorriston \\ Department of Economics \\ University of Exeter
}

\begin{abstract}
In this paper, we consider the short and long-run performance of UK firms following foreign acquisitions. Based on a near-exhaustive sample of significant foreign acquisitions by UK companies over the period 1985-1994, we show that short-run returns are insignificantly different from zero irrespective of the location of the acquisition. Further analysis reveals that the distribution of the event period returns is determined by changes in the exchange rate, the presence of the acquiring firm in the target country and by US tax reforms. While long-run returns are not significantly different from zero on average, they show considerable variation by region. Specifically, firms under-perform following acquisition in the US, show insignificant returns following acquisitions in the EU and acquisitions elsewhere show significant positive returns. Examination of the distribution of these returns suggest that, in accordance with the ownership-location-internalisation hypothesis of FDI, long-run performance is more likely to depend on the firm-specific advantages such as R\&D.
\end{abstract}

\section{Keywords: Foreign Acquisitions; Long-Run Performance. JEL Classification: G34}

\section{Acknowledgments}

The authors would like to acknowledge the helpful comments of participants at the EFM Conference in Athens, in particular those of Mario Levis (City University, London) who acted as discussant on an earlier draft of the paper, and participants at the IESE, Barcelona, Conference on Corporate Governance, together with seminar participants at the University of Bristol, City University and University of Exeter for comments on a later draft. Comments from two anonymous referees are also appreciated. We would like to thank Richard Paterson of the University of Exeter for his excellent research assistance on this project and Maria Michou for additional help with the data.

*Corresponding Author:

Professor Alan Gregory, email: A.Gregory@exeter.ac.uk 


\section{Foreign Acquisitions by UK Limited Companies: Short and Long- Run Performance}

\section{Introduction}

A key feature of the world economy since the mid-1960s has been the remarkable growth of foreign direct investment (FDI). The growth of FDI has out-stripped the growth of income four-fold and trade three-fold. The growth in FDI has been particularly marked since the mid-1980s with the world economy witnessing a dramatic surge such that FDI has become the most common means of serving foreign markets. Indeed, in terms of the recent focus on 'globalisation', 'globalisation of production' now exceeds 'globalisation through trade'. Furthermore, this growth of FDI has involved most developed countries. For example, the US witnessed a surge in both FDI outflows and inflows with the latter increasing so rapidly that the US became a net importer of FDI in the late 1980s. In the case of the EU, FDI both within the EU and between EU and non-EU countries increased rapidly. The main exception to the simultaneous growth of FDI involving developed countries relates to Japan which witnessed considerable growth in FDI outflows while FDI inflows into Japan remained at low levels.

A key characteristic of the dramatic growth in FDI since the mid-1980s is the form it has taken. FDI can take a variety of forms including the establishment of 'green-field' sites and joint ventures. However, the most prevalent form of FDI is via cross-border acquisitions. For example, in the US, on average over the 1984-1995 period, crossborder acquisitions accounted for over 90 per cent of US FDI inflows. In the EU, cross-border acquisitions have also dominated FDI flows involving both EU and nonEU countries. For the UK, cross-border acquisitions also account for the main form of FDI. For example, in 1998, cross-border acquisitions accounted for around 80 per cent of FDI outflows ${ }^{1}$. Moreover, cross-border acquisitions have risen markedly in recent years: in 1995, the value of acquisition purchases by the UK was almost $\$ 30 \mathrm{~m}$ but by 1999 this had risen to \$209m. For developed countries as a whole, cross-border mergers and acquisitions grew from around \$173m in 1995 to $\$ 677 \mathrm{~m}$ in 1999. While

\footnotetext{
${ }^{1}$ This data comes from World Investment report 2000: Cross-Border Mergers and Acquisitions and Development, UNCTAD (2000).
} 
there may be some variation between countries, industries and years, the dominance of cross-border acquisitions is such that we can relate the surge of FDI since the mid1980s as being synonymous with a surge in international acquisitions.

The aim of this paper is to consider the short and long-run performance of UK firms which made acquisitions during the 1984-1994 period. Since the UK is a leading player in international acquisitions, the study of UK acquisitions abroad is an important aspect in determining the overall success of FDI by acquisition. For example, Healy and Palepu (1993) note that, over the late 1980s, the UK was the lead acquiring nation in international acquisitions accounting for almost 30 per cent of international corporate investments over that period. As an acquirer nation, the US accounted for around 14 per cent of total acquisitions over the same period ${ }^{2}$. The focus on the UK departs from most recent studies that look at either the US or Japan as the source of acquiring firms or, more commonly, with the US as host with the returns to bidding firms varying across the source countries.

Although some (albeit limited) research on the returns to shareholders of bidding firms involved in international acquisitions exists, we depart from this literature in several important respects. The first, for the reasons explained above, is in the focus of attention being the UK on which the literature is fairly scant. The second is the comparison between short and long-run abnormal returns with most studies to date focussing solely on announcement period effects. Third, while we apply standard event study methodology to derive the announcement period effects, to our knowledge, this is the first study of FDI decisions that employs the Lyon et al (1999) "bootstrapping” method in testing for long-run abnormal returns. Moreover, we relate these results to the literature on foreign direct investment in order to explain the distribution of returns across the acquiring firms that comprise our sample.

Most recent studies have focussed on the effect of the acquisition around the event (acquisition) date. However, positive abnormal returns (if they exist) may dissipate

\footnotetext{
${ }^{2}$ This ranking obviously varies each year depending on country and firm specific determinants of FDI. For example, in 1996, the UK accounted for 16 per cent of cross-border acquisitions world-wide while
} 
over the long-run. This has been the focus of recent research in the finance literature which suggests that the announcement period returns may not fully reflect the wealth effect of an event ${ }^{3}$. This may be true of cross-border acquisitions particularly if the acquisition, and the premium paid, is influenced by short-run factors such as the presence of multiple bidders in a given acquisition, a given level of the exchange rate, changes in legislation, or the perception of increased protectionism (e.g. the creation of

the 'Single Market' in the EU). For example, recent studies focussing on shareholders' wealth in target firms following cross-border acquisitions (around the event date) have highlighted the role of the US dollar and changes in US tax laws (see below). While this may influence the returns around the acquisition date, it may not reflect the wealth effect of the acquisition over the long-run. There is an extensive literature that documents the long-run under-performance of domestic acquirers, which is major issue in explaining the rationality of merger activity by firms (for a review of this literature, see Agrawal and Jaffe, 2000). Therefore in this paper we also pay special attention to the long-run performance of UK acquiring firms, which may differ from the abnormal returns associated with the acquisition event. Significantly, we provide evidence on specific acquirer characteristics that appear to be associated with long-run post-bid performance and show that these are in line with predictions drawn from the ownership-location-internalisation theory of FDI.

Our (near exhaustive) sample of significant acquisitions by UK acquiring firms allows us to assess whether there is any variation in performance in the nature of UK acquisitions abroad. Whilst the results show that foreign takeovers by UK firms produce returns that are, on average, negative but insignificantly different from zero in both the short and long-run, digging deeper into the data reveals important differences in acquirer performance that reflect both target market and acquirerspecific differences. Specifically, there is variation in abnormal returns depending on country of acquisition and on the period in which returns are measured. Sub-analysis shows that acquisitions in the US produce returns in the short-run that are positive but 
not significantly different from zero; however, over the long-run, returns following acquisitions in the US are both economically and statistically significantly negative. Negative abnormal returns exceed 27\% over the 5 years post-takeover. By contrast, EU takeovers yield insignificantly negative returns around the acquisition event though they exhibit positive abnormal returns over a 5-year period though they are still not significantly different from zero. With reference to the relatively small sample of takeovers (39 acquisitions) in the rest of the world, they produce positive returns in the short-run though they are not significantly different from zero; however, in the long-run, these acquisitions in the rest of the world produce significantly positive abnormal returns. Partitioning results on degree of relatedness shows that abnormal returns in same-SIC takeovers are an insignificant $-3.6 \%$ after 5 years, whilst conglomerate (different principal SIC code) takeovers yield a significant 21.8\% abnormal return over the same period. However, both same SIC and conglomerate takeovers yield significant negative abnormal returns within the US. This partitioning of the sample by industry relatedness does not seem to influence returns around the event date.

Finally, our regression tests show that the determinants of event period returns are more likely to be associated with short-run factors such as policy changes (the US tax reforms in the mid-1980s) and the exchange rate but these factors are of little significance in explaining long-run performance. In terms of regression tests of the long-run performance, firm-specific advantages in the form of $R \& D$ are the most important factor in explaining why some firms do better than others. Our results also confirm that US acquisitions are value-reducing events, but also provide evidence that $\mathrm{R} \& \mathrm{D}$ and the presence of a hostile bidder have a role to play in explaining abnormal returns over a 5-year period. Overall, the results show that the returns around the event date can differ both economically and statistically from long-run returns and the factors that determine the performance over a given period can also vary. As such, the difference between the event period and long-term abnormal returns and the factors that appear to cause them may be a source of concern given that what determines the long-run performance post-acquisition will be quite different from what will determine returns in the short-run. This would suggest that the market does not 
appropriately characterise what will determine shareholder wealth just by looking at the event period returns.

The paper is organised as follows. In section 2, we present a brief review of the literature on wealth effects on bidding firms involved in cross-border acquisitions and how this has been related to the literature on foreign direct investment. In section 3, we discuss the data that forms the basis of the sample used to assess the performance of UK firms while, in section 4, we present the research method. In section 5, the results are reported while in section 6 we report the principal conclusions and what the results may infer about the post-acquisition performance of UK firms.

\section{Related Literature}

(a) Post-Acquisition Performance of Acquiring Firms

While cross-border acquisitions have received some attention in the finance literature (most commonly on the impact on the target firm) only a limited body of research exists on the impact of cross-border acquisitions on returns of acquiring firms. For example, Doukas and Travlos (1988) focus on US acquiring firms and find that, on average, there is no significant impact on bidders' wealth. However, there is considerable variation over their sample of firms with positive abnormal returns arising if the acquiring firm is entering new markets or new industries. The authors regard this evidence as supporting the multinational network hypothesis, the rationale here being that there are lower (higher) marginal returns if the acquiring firm already has (does not have) a presence in the target country. Other studies that have focussed on returns to bidders based on a sample of US firms include Fatemi and Furtedo (1998), Markides and Ittner (1994) and Datta and Puia (1995) all of which find either non-significant positive abnormal returns or, in the case of Datta and Puia, negative abnormal returns. In terms of non-US countries, Kang (1993) investigates the abnormal returns of Japanese bidders in the US and finds positive abnormal returns to Japanese firms. Corhay and Rad (2000) find weak evidence that cross-border acquisitions are wealth-creating based on a sample of Dutch firms. They also find evidence that the benefits from internalisation are greater for firms having less international exposure and making acquisitions outside their main industrial activity. In terms of cross-country comparisons, Eun et al. (1996) have shown that the returns 
to acquiring firms are likely to vary across countries. Examining cross-border acquisitions in the US, they show that bidding firms sourced from Japan experienced positive abnormal returns while UK firms experienced considerable negative abnormal returns. Acquiring firms based in Canada experienced mildly positive abnormal returns that were considerably below those experienced by Japanese firms ${ }^{4}$. Cakici et al. (1996) also report significantly positive abnormal returns around the event date for acquirers from Japan, Australia, the UK and the Netherlands.

These studies suggest that positive abnormal returns are likely to vary depending upon the characteristics of the investing firms, the country of origin, and the country and/or industry in which the acquiring firm is investing in. However, all these studies are linked by a similar characteristic i.e. they all measure the impact on the acquiring firm around the date of the acquisition event. In this paper, the focus is extended to evaluate the returns of the acquiring firm over the long-run as short-run event studies may not fully reflect the wealth creating or destroying impact of an acquisition and that a measured positive/negative impact (if any) may be determined by factors corresponding with the event date. Such an extension is particularly relevant if the acquisition is intended to be value-creating (say, through synergy). Clearly, aside from the immediate impact of the acquisition event, identifying the long-run performance of international acquisitions is important in assessing the overall impact of FDI. The only other paper to look at longer run returns for this group of acquirers is that of Conn et al. $(2001)^{5}$. That paper uses a control firm approach, with matching on size and prior performance, with significance measured by standard ttests and the Wilcoxson matched pair signed rank tests, in contrast to the Lyon et al. method we describe below. The sample period and returns accumulation period are also different with returns being accumulated up to 36 months post-takeover. ${ }^{6}$ However, results are broadly similar between the two studies, with the exception that we find stronger negative returns for the US sample. The most likely explanation for this difference is the deterioration in performance between the 36 and 60-month horizons, which we describe below. Moreover, we also formally test for the

\footnotetext{
${ }^{4}$ Conn and Connell (1990) compared the returns of US and UK bidding firms.

${ }^{5}$ Moeller et al. (2003) have recently explored the issue of short and long-run returns using a sample consisting of US firms involved in domestic acquisitions.

${ }^{6}$ Less for later periods in the sample
} 
determinants of performance following foreign acquisitions over both the short and long-run periods.

\section{(b) Relating Performance to Determinants of FDI}

There are two broad themes that have emerged in the economics literature on the rationale for foreign investment and that have been reflected in the finance literature on the returns of acquiring firms following cross-border acquisitions. The economics literature on foreign direct investment places emphasis on the ownership-locationinternalisation (OLI) paradigm which suggests a combination of factors would lead to an incentive for invest overseas. ${ }^{7}$ In broad terms, firms engage in FDI due to the possession of substantial intangible assets (ownership) related to which there are difficulties in exploiting such assets through alternative means due to market failure (internalisation), the role of product or factor market imperfections also being noted by Harris and Ravenscraft (1991). Typically these intangible assets are measured as $\mathrm{R} \& \mathrm{D}$ as a percentage of sales. The location aspect of the OLI paradigm stresses advantages of FDI in specific countries/regions in combination with firm-specific ownership factors and the problems of internalisation. These issues have been highlighted in the finance literature on overseas takeovers. For example, Mork and Yeung (1992) have highlighted the relevance of the OLI framework in an event study of US acquisitions. Specifically they report positive abnormal returns for US firms from international acquisitions if the acquiring firm possesses firm-specific intangible assets as reflected in high levels of $R \& D$ expenditure and/or advertising expenditure, the possession of these assets being most commonly associated with the characteristics of firms likely to invest abroad as outlined in the traditional literature on FDI. In contrast, Cakici et al. (op. cit.) find no role for R\&D in determining event period returns.

Another theme in the literature on foreign direct investment has related to the role of capital market imperfections and the role of exchange rates commonly associated with Froot and Stein (1991). They have hypothesised that foreign buyers will have a comparative advantage in buying a domestic company when the foreign currency is 
relatively strong. In essence, an appreciation of the acquiring country's currency should increase the relative wealth of the acquiring firms which allows firms to overcome capital market constraints and hence increase acquisitions. A different variant of the exchange rate argument is provided by Blonigen (1997) who argues that changes in the exchange rate leads to a change in the valuation of the expected stream of returns from an asset acquired in a foreign country.

While these papers essentially focussed on explaining the rise foreign acquisitions in the US around the late 1980s, others have focussed on US tax reforms that occurred in 1986. Important in this regard is the US Tax Reform Act of 1986, which Scholes and Wolfson (1990) argue helped the relative position of foreign investors compared to the position for foreign buyers under the 1981 Economic Recovery Tax Act. The issue here was that the US Economic Recovery Tax Reform Act of 1981 increased tax incentives for domestic takeovers which allowed rapid depreciation write off and investment tax credits. The 1986 Tax Reform Act reversed these incentives and thus, it is argued, would have lead to more foreign acquisitions of US companies. More specifically, the Scholes and Wolfson argument should be reflected in more acquisitions by foreign companies in the US particularly from countries that apply the world-wide principle for taxing profits earned abroad ${ }^{8}$.

The finance literature has also reflected these themes in the literature in order to explain returns around the event date. For example, Swenson (1993) and Dewenter (1995a) have found the role of the exchange rate to be a significant factor in determining returns to target firms while Dewenter (1995b) finds some evidence for the role of tax reform changes though the evidence is rather weak. Kang (op. cit.) reports evidence that the gains to Japanese acquirers is positively related to the weakness of the US dollar. In contrast, Cakici et al. (op. cit.) find no role for the exchange rate or the impact of US tax reforms in explaining the returns to acquirers of US firms. Rather Cakici et al. find that the gains to the acquirers are more likely to be affected by the presence of hostile bidders.

\footnotetext{
${ }^{7}$ For a summary of internalisation theory, see for example, Dunning (1993).

8 The world-wide principle involves the taxation of profits earned world-wide but grants credits on foreign taxes paid. The UK and Japan would fall into this category.
} 


\section{(c) Further Considerations}

Several studies of cross-border acquisitions have highlighted the variation in the gains across acquiring countries. This is noted in the studies by Eun et al. (op. cit) and Cakici et al. (op. cit.) though there is often little rationalisation as to why crosscountry variation in post-acquisition performance should exist. Corhay and Rad (op. cit.) also note cross-country variation in returns but justify their segmentation of the data on the basis that corporate governance varies between countries with, for example, the EU having different legal and institutional regulations compared with the US which may influence the cross-country distribution of foreign acquisitions. This fits with recent work on how corporate governance varies between countries. Most notable in this regard are the recent papers by La Porta et al. (2000, 2001). They note that there is significant variance in the characteristics of corporate governance throughout the world and that this varies with the nature of the legal system in countries that comprise their sample. Most notable for our purposes is that the UK has a very similar corporate governance structure to that of the US, both of which are based on common law. In contrast, many European countries have different corporate governance structures reflected in concentration of ownership, shareholders' rights and so on. As noted by La Porta et al., the legal system in many European countries is based on civil law. Recently, Rossi and Volpin (2003) have related this variation in the characteristics of corporate governance to the cross-country determinants of crossborder acquisitions. They argue that the role of corporate governance on valueenhancing acquisitions is ambiguous. On the one hand, acquisitions from high to low investor protection countries may lead to higher premiums reflecting the anticipated gains in efficiency as stronger corporate governance standards extend over firms with weaker standards. Alternatively, lower demand for acquisition deals in countries with lower standards would lead to lower premiums. In terms of UK acquisitions in the US which (where according to the data reported by La Porta et al. (2001) the US and the UK have similar corporate governance structures), the premium may reflect competition among bidders though this is likely to interact with other control variables such as the exchange rate and the US Tax Reform Act which will influence the relative competitiveness of foreign versus domestic acquirers of US firms. While these variables would have reduced the competitiveness of domestic versus overseas 
bidders, it would have increased competition among foreign acquirers for US targets. More generally, Rossi and Volpin conclude that variation in corporate governance is an important influence on the distribution of cross-border deals and the premiums associated with such acquisitions.

Reflecting this recent literature we also segment our sample by target country. Most importantly, we separate out the experience of UK firms acquiring companies in the US and the EU. The US sub-sample is justified on the basis that it has a similar legal system to that of the US with many of aspects of corporate governance being similar between the US and UK. Acquisitions in the US also form the majority of targets in our sample. The EU forms another sub-sample. The argument for treating the EU as a block is based not solely on the policy changes associated with the creation of a larger market and the Single Market Programme but also due to the similarities in corporate governance between EU countries. Although La Porta et al (2001) report variation in corporate governance indicators across the EU, the Single Market Programme aimed to bring about a harmonisation of Western European laws including those relating to corporate governance (see La Porta et al. (2001, footnote 2). For the remaining countries in our sample, we treat them as a Rest of the World residual.

Taken together, the paper considers the event period and long-run returns of UK acquiring firms. Having measured post-acquisition performance, the aim is to relate the distribution of these returns to the explanatory factors that have been highlighted in the finance and economics literature. We also segment our sample according to target country on the basis that variation in acquiring returns may exist according to differences in the nature of corporate governance.

\section{Data}

The sample is drawn from the set of all overseas acquisitions recorded by Amdata with bid values and sales of acquirer and target companies available. In order to ensure that only economically significant deals are analysed, we use the cut-off that target sales must be at least $5 \%$ of acquirer's sales in the financial year preacquisition. This necessarily requires data to be available on the target's sales. Whilst this has the disadvantage of eliminating many (mainly non-US) takeovers, it 
screens from the sample the many examples of takeovers of small and closely-held firms which may not be economically significant events. We also require both an announcement date and a completion date to be available on Amdata. These data requirements lead to an initial sample of 343 acquisitions.

Table 1 here

The method used to calculate post-bid abnormal returns imposes additional data requirements on this initial sample as we match acquiring firms by market capitalisation and by book-to-market ratio. It is well known that these characteristics have an important role in explaining the cross-section of returns in both the US and the UK (e.g. Fama and French, 1992, 1996; Strong and Xu, 1997; Gregory, Harris and Michou, 2001). To match on these characteristics, we require the market capitalisation of the firm from the London Business School Share Price Database (LSPD) and the book-to-market ratio to be available from Datastream. In all, these data requirements result in a slightly reduced sample size for the long-run returns of 333 firms. A summary of the characteristics of our sample of UK foreign acquisitions is provided in Table 1 . Note that we do not segregate our sample between cash and equity bids, as prior to the late 1990s foreign bids financed by equity were highly unusual events.

\section{Methodology}

\section{(i) Event Period Returns}

In deriving the short-run returns around the event date we apply standard event study methodology. Specifically, we use cumulative abnormal returns (CAR) to measure the takeover premia for acquiring firms where the daily stock return for company $i$ is given by:

$$
R_{i t}=\alpha_{i}+\beta_{i} R_{m t}+\varepsilon_{i t}
$$

with the expected stock return being given by:

$$
E\left(\hat{R}_{i t}\right)=\hat{\alpha}_{i}+\hat{\beta}_{i} R_{m t}
$$

The abnormal return (AR) for company $i$ is given by: 


$$
A R_{i t}=R_{i t}-E\left(R_{i t}\right)
$$

The cumulative abnormal return (CAR) is therefore measured over an event window and is given by:

$$
C A R_{i}=\sum_{t=-n}^{t=m} A R_{i t}=\sum_{t=-n}^{t=m} R_{i t}-\hat{\alpha}_{i}-\hat{\beta}_{i} R_{m t}
$$

where $(t=-n, t=m)$ is the size of the event window ${ }^{9}$. In deriving the CARs, expected returns are based on a 250-day window prior to the announcement of the foreign acquisition. We considered two event windows: a relatively short 5-day window $(-3,1)$ and a longer event window $(-10,10)$.

\section{(ii) Long-Run Returns}

Our first and main group of tests in deriving the long-run returns involves the use of buy-and-hold returns compared to reference portfolios of firms with similar size and similar market-to-book ratios. We then undertake statistical inference tests using the bootstrapping approach of Ikenberry et al (1995) and Lyon et al, (op. cit.). The motivation here is to avoid the biases in the more traditional CAR approach documented in Kothari and Warner (1997), although as Ikenberry et al (op. cit., p. 188) note, the buy-and-hold approach also represents a more feasible investment strategy than that implied by the CAR model. Briefly, the Ikenberry et al (op. cit.) method involves matching the returns on the portfolio of acquiring firms with a reference or control portfolio consisting of firms with similar size and book-to-market characteristics. Statistical inference is made by generating an empirical distribution of long-run returns under the null hypothesis from this matched group. This is done by randomly selecting a characteristic-matched firm for each acquiring firm and treating this matched firm as though it had announced an acquisition on the actual announcement date. This portfolio of matched firms is termed a "pseudo-portfolio" by Ikenberry et al (op. cit., p. 189). Long-run performance is then estimated for the pseudo-portfolio and the experiment is repeated 1,000 times, yielding 1,000 abnormal return observations and an empirical approximation of the distribution of these abnormal returns drawn under the null hypothesis.

\footnotetext{
${ }^{9}$ We also repeated our tests using a simple market-adjusted return metric (equivalent to setting $\alpha=0$ and $\beta=1)$. The results were not materially different from those reported.
} 
For this analysis we form decile and quintile reference portfolios. The ten size reference portfolios are formed using the year-end market capitalisation data from the London Business School Share Price Database (LSPD), the same source we use for company total returns. Each size reference portfolio is then partitioned into five bookto-market quintiles using end-June book-to-market ratios from Datastream. Reference portfolios are then formed at the end of June each year and returns are calculated using the "buy-and-hold” method described in Lyon et al, (op. cit., p. 169):

$$
R_{p s \tau}^{b h}=\sum_{i=1}^{n_{s}} \frac{\left[\prod_{t=s}^{s+\tau}\left(1+R_{i t}\right)\right]-1}{n_{s}}
$$

where $\tau$ is the period of investment in months, $R_{i t}$ is the return on security $i$ in month $t$, and $n_{s}$ is the number of securities traded in month $s$, the first period for the return calculation. This represents the return on a passive investment portfolio.

We define the expected return on acquirer $i$, $\left[\mathrm{E}\left(R_{i \tau}\right)\right]$ as the reference portfolio buyand-hold return given by (1). Abnormal returns are then defined as:

$$
A R_{i \tau}=R_{i \tau}-E\left(R_{i \tau}\right)
$$

Returns are then calculated for up to 60 months post-completion.

Given the well-documented biases in long-run return calculation, the test statistics we report are the bootstrapped skewness-adjusted t-statistic and pseudo-portfolio empirical $p$ value methods outlined above and described in detail in Lyon et al (op. cit., pp 173-176). We follow their method precisely, save for the fact we have 50 portfolios (10 size x 5 book-to-market) as opposed to their 75 portfolios. ${ }^{10}$ The abnormal return on the pseudo-portfolio is then calculated from (1'). This procedure is then repeated 1000 times, yielding an empirical distribution of abnormal returns drawn under the null hypothesis. We use this to estimate empirical $p$ values for $10 \%$, 5\% and 1\% levels following Lyon et al (op. cit.). These are then used to assess the significance of the sample of acquirer abnormal returns estimated from (1').

\footnotetext{
${ }^{10}$ Note that we use fewer portfolios principally because of the smaller number of stocks present on the UK stock exchange.
} 
Using the same notation as Lyon et al (op. cit.), we estimate the bootstrapped skewness-adjusted $t$-statistic as:

$$
t_{s a}=\sqrt{n}\left(S+1 / 3 \gamma S^{2}+1 / 6 n \hat{\gamma}\right)
$$

where:

$$
S=\frac{A \bar{R}_{\tau}}{\sigma\left(A R_{\tau}\right) / \sqrt{n}}, \quad \hat{\gamma}=\frac{\sum_{i=1}^{n}\left(A R_{i \tau}-A \bar{R}_{\tau}\right)^{3}}{n \sigma\left(A R_{\tau}\right)^{3}},
$$

$A \bar{R}_{\tau}$ is the sample mean, and $\sigma\left(A R_{\tau}\right)$ is the cross-sectional sample standard deviation of abnormal returns. The bootstrapping employed involves drawing 1000 bootstrapped re-samples from the original sample of size $n_{b}=n / 4$. In this choice of re-sampling size, we simply follow the recommendations of Lyon et al, but a discussion of alternative re-sampling sizes can be found in Lyon et al (op. cit., p. 174). For each re-sample, the analogue of (4) above is recalculated using the smaller sample, $n_{b}$, in place of $n$. As for the pseudo-portfolio empirical tests, we calculate the two critical values of the distribution of the 1,000 re-samples for $p=10 \%, 5 \%$, and $1 \%$.

We also calculate long-run CARs for our sample using the Fama-French three factor model, although we do not report them in detail. We calculate these for two reasons: first, as a robustness check on the pseudo-portfolio approach; second,whilst CARs have their disadvantages, standardised CARs can be used in regression tests, which has the advantage of avoiding some problems relating to heteroscedasticity. The CAR analysis leads to results that in general are qualitatively similar to those obtained from the pseudo-portfolio approach, though the CARs are less negative than the buyand-hold abnormal returns, as would be expected given the positive biases documented in Kothari and Warner (op. cit.). 


\section{Results}

\section{(i) Short-Run Returns}

The results presented in Table 2 show the estimated CARs with an event window (3,1). For UK acquisitions as a whole, the CARs for UK acquiring firms are negative but not statistically significant. However, for US acquisitions short-run returns are positive but again not statistically significant. The CAR results for investment in other regions vary being negative for acquisitions in the EU and positive for those in the rest of the world but neither is statistically significant. Partitioning the sample of acquisitions according industry relatedness show that neither acquisitions in the same industry or conglomerate acquisitions generates statistically significant abnormal returns, our definition being based upon whether the two-digit SIC code of acquirer and target are coincident. Although the results presented in Table 2 relate to a relatively small window $(-3,1)$, extending the CAR methodology to a larger window has no bearing on the overall results. Specifically, using a $(-10,10)$ window, the only changes that occur are that the wealth gains for acquisitions in the US and for conglomerate acquisitions become negative but are not statistically significant in either case. Since no other results change, we do not present the results for the larger window. On the whole, our finding of insignificant negative returns contrasts with the event period findings of Eun et al (op.cit.), who find that UK acquirers perform worse than any other nationality in making US acquisitions while Cakici et al. (op. cit.) report positive returns for UK firms around the event date.

Table 2 Here

\section{(ii) Long-Run Returns}

In Table 3 we present the overall results relating to long-run returns. This table shows that the 1-year, 3-year and 5-year post acquisition returns for UK foreign acquirers are negative but not significantly different from zero ${ }^{11}$. Following Rau and Vermaelen (1998), we report the abnormal returns for the sample by the book-to-market ratio. After 3 years, there does appear to be weak evidence of a "value” effect, with the high

\footnotetext{
${ }^{11}$ The CARs for 12,36 and 60 month periods are $+1.2 \%,-0.1 \%$ and $-4.8 \%$ respectively. None of these CARs are statistically significant.
} 
book-to-market (or "value” group) having positive returns, whilst the lowest returns are found in the low book-to-market (or "glamour" group). These results are broadly in line with those of Rau and Vermaelen. However, after 5 years there appears to be no monotonic relationship between the book-to-market ratio and acquirer performance. Although the high book-to-market group still have the highest overall abnormal returns after 5 years, the second largest abnormal return is associated with the low book-to-market group over this period, although only in the former group are abnormal return positive. The overall impression from the 5-year returns is that abnormal returns are "U” shaped with respect to book-to-market groupings. Although we report the two test statistics for each quintile, the small sample size in each quintile imposes quite demanding limits for any of the figures to be statistically significant. Nonetheless, the fact that the median BTM quintile yields negative abnormal returns significant at the $10 \%$ level in both tests reinforces the impression of a "U" shaped distribution of abnormal returns. This longer-horizon result stands in contrast to the results of Rau and Vermaelen, the relevant comparison being with the cash acquirers reported in their Table 6, Panel B, where they report that the abnormal returns to US cash-financed mergers ${ }^{12}$ for “glamour" acquirers was $-11.5 \%$ after 36 months, but for "value" acquirers the abnormal returns were $+11.69 \%$ over the same period. However, whilst Rau and Vermaelen partition their sample on a relative basis (i.e. the top 50\% of acquirers by BTM are "value” firms), we partition on an absolute basis (i.e. on the basis of the BTM quintile to which the acquirer belongs). It is noticeable that by this definition the majority of our acquirers would be "glamour" firms. For our full sample it appears that there is little evidence to support a “performance extrapolation” hypothesis of bidder returns.

Until very recently foreign takeovers by UK companies almost universally involved cash, cross-border equity transactions being an innovation that largely post dates our sample. Most studies in the US and the UK document that domestic acquisitions financed by cash exhibit returns not significantly different from zero. ${ }^{13}$ Thus overall

\footnotetext{
${ }^{12}$ Whilst the terminology differs in UK acquisitions, the vast majority of our sample are non-hostile bids, which roughly equates to a "merger" in US terminology; as noted, during our sample period it was extremely difficult for a UK company to acquire an overseas firm for anything other than cash. ${ }^{13}$ Although Gregory (1997) in a study of UK domestic acquirers for 1984-92 provides weak evidence that cash acquirers may under-perform, in that returns are just significantly negative under some benchmarks.
} 
the pattern found for cross-border takeovers by UK companies is similar to that found in domestic acquisitions. As above, we partition our data according to whether the takeover is of a US, non-UK EU or other ("Rest of the World", RoW) domiciled company and partition the sample into conglomerate and non-conglomerate takeovers. All partitioned results are obtained by re-running the Lyon et al method for the relevant sub-sample.

\section{Table 3 about here}

The analysis by geographical region reported in Table 4 highlights the fact that mean US-target abnormal returns are a significantly negative $27.09 \%$ at the $1 \%$ level for the 5 years post-takeover using both the bootstrapped skewness adjusted t-test and the $p$ level from the empirical pseudo-portfolio distribution. The 3-year post-takeover abnormal returns of $-9.36 \%$ are significant at the $5 \%$ level using the former test, but only at the $10 \%$ level using the latter, whilst the $0.19 \%$ 1-year abnormal returns are not significant. Thus our analysis shows that the majority of the abnormal returns on acquisitions of US targets occur between months 36 and $60 .{ }^{14}$ In the case of acquisitions in the EU, the abnormal returns for the 5-year abnormal returns are insignificantly positive, whilst those for the 3 year and 1 year intervals post-takeover are insignificantly negative. For the rest of the world, abnormal returns are positive and significantly so. Given the small number of Rest of the World acquisitions (39 cases) and their geographical spread, it is difficult to make any strong claims for the success or otherwise of these takeovers, but we find the 3-year and 5-year returns post-takeover are significant at the $5 \%$ and $10 \%$ levels for the two periods respectively.

Table 4 here

The results from the partition of our acquirers' long-run returns on the basis of whether they are in the same industry (same 2-digit SIC) or not are reported in Table 5. As might be expected, if synergistic benefits provide a motivation for takeovers, same industry acquirers perform significantly better than conglomerate acquirers.

\footnotetext{
${ }^{14}$ This appears to be a critical factor in explaining the difference between our results and those of Conn et al (op. cit.)
} 
Same-SIC code takeovers yield abnormal returns that are neither economically nor statistically significantly different from zero at 1-year, 3-year or 5-year horizons. These acquisitions yield returns of $-2.3 \%$ after 1 year, $-4 \%$ after 3 years, and $-3.6 \%$ after 5 years. By contrast, conglomerate acquisitions (defined as being takeovers in a firm with a different 2-digit SIC) yield modest negative abnormal returns over the 1 and 3 year horizons, but a significant $-21.8 \%$ after 5 years.

\section{Table 5 here}

Given the significant negative returns associated with US acquisitions, we further analyse these acquirers of US target returns by same SIC/ different SIC and by BTM quintile. These results are reported in Table 6.

\section{Table 6 here}

Surprisingly, there is little difference between conglomerate and non-conglomerate groups in the US in terms of the absolute level of abnormal returns. The same SIC group show abnormal returns of $+2.7 \%,-11.1 \%$ and $-29.6 \%$ over 1,3 and 5 year horizons respectively, whilst the conglomerate group have abnormal returns of $-4.5 \%$, $-6.3 \%$ and $-22.5 \%$ over the same periods. Although the same SIC group perform somewhat worse over the 5-year period, both are statistically significant and it seems probable that the difference in significance levels has more to do with the relative sample sizes (128 compared to 69) than the size of the abnormal returns.

Turning to the returns by BTM quintile, no obvious pattern emerges from the analysis. In line with the Rau and Vermaelen (op.cit.) results, the "glamour” group show the worst overall returns over both the 3-year (a significant-18.44\%) and 5-year (a significant $-45.2 \%$ ). However, the least poor performers are the BTM 2 group (9.8\%) over 5-years, which would be classified as a "glamour" grouping. The other significant under-performers are the BTM 4 group which constitutes a "value" grouping. 
Based on the analysis so far, it appears that the most robust fact is that British firms simply make poor US acquisitions when the long-run evidence is taken into account. This is not explained by either "performance extrapolation" factors, nor any theories connected with conglomerate versus non-conglomerate acquisitions. It may be that the differences in returns across countries/regions may reflect differences in corporate governance and/or the extent of competition in the market for corporate acquisitions. However, it is particularly notable that these long-run results represent a reversal of the event period results which were positive but statistically insignificant. The difference between these short and long-run results may also reflect differences in the factors that explain the distribution of abnormal returns in the firms that comprise our data set. We therefore turn to regression tests designed to tease out further insights into the factors that might explain the performance of UK acquirers of overseas targets.

\section{Regression Tests}

As noted in the section 1, there are two broad themes in the literature that have been used to examine the determinants of returns to acquiring firms following foreign acquisitions. The first relates to the internalisation or exploitation of monopoly rents hypotheses that predict that a firm's ability to derive abnormal profits through takeover should stem from its "knowledge asset” base (Dunning, (op.cit.) and Morck and Yeung, (op.cit.)) reflected in the ownership of intangible assets, whether the acquirer already had a presence in the target market (Harris and Ravenscraft, (op.cit.)) and the degree of industry relatedness. While the firm and industry-specific determinants of acquirers' returns should be informative about the distribution of returns over a cross-section of firms, there are further issues to be considered in terms of the timing of the acquisition decision. This is the second theme in the finance literature that has focussed on macro-economic determinants particularly the importance of the exchange rate and the impact of US tax policy reforms with respect to acquisitions in the US.

To test these hypotheses, we ran regression tests with event period (short-run) abnormal returns as well as the long-run abnormal returns over the 5-year period as 
dependent variables. A potential problem with using untransformed abnormal returns in regression tests is that of heteroscedasticity. Most papers that undertake regression tests to investigate the distribution of abnormal returns use either standardised CARs as the dependent variable or adopt a weighted least squares approach. We follow this well-established model of using standardised CARs for the regressions of short-run returns, but this does raise the issue of how to treat the regressions of long-run returns. Controlling for heteroscedasticity using weighted least-squares, with weights being the inverse of the standard prediction error, or standardising CARs using the same prediction error, is not possible when using the pseudo-portfolio method is used to estimate abnormal returns, so for our regression tests we re-estimate the abnormal returns using the Fama-French three-factor model estimated over the 60 months posttakeover. The standardised CARs from this model are used in the regression tests described below. ${ }^{15}$

In each case, we included the following independent variables which relate to the various hypotheses relating to the foreign acquisition literature as discussed above:

$U S$ = dummy variable equal to one if the acquisition is made in the US $E U=$ dummy variable equal to one if the acquisition is made in the EU USTAX = dummy variable equal to one if the takeover was of a US company and occurred prior to the introduction of the 1986 Tax Reform Act EXCHRATE =the US\$/£ rate for takeovers in the US and ROW, or the DM/£ rate for acquisitions in the EU matched to the deal announcement date. This variable was used in the regressions relating to the short-run (event period) CARs. For the long-run returns, we used DCURR (see below)

DCURR5 = the change in the $\$ / £$ rate for takeovers in the US and ROW, or the $\mathrm{DM} / £$ rate for takeovers in the EU, measured over 5 years post takeover ${ }^{16}$ $R \& D I N T=$ the industry $\mathrm{R} \& \mathrm{D}$ as a percentage of sales (see below) $A D V I N T=$ the industry advertising expenditure as a percentage of sales (see below)

\footnotetext{
${ }^{15}$ We also estimated the regression tests using the untransformed abnormal returns from the Lyon et al procedure described above. The results are generally similar, but considerably weaker with lower Rsquared statistics. A copy of these results is available from the authors on request.

${ }^{16}$ We tried alternative measures of the exchange rate variable including real and nominal. There was little difference between them. The results reported relate to changes in the nominal exchange rate.
} 
SAME SIC = dummy variable equal to one if the acquisition is made in an industry with the same 2-digit SIC code

HOSTILE = dummy variable equal to one if the acquisition was a hostile bid FORSALES=sales in the target region by acquiring firm in the year prior to acquisition.

The first two variables segment the data by geographical region. As discussed in section 1, the US has a similar corporate governance structure to that of the UK while the EU has notable differences. Nevertheless, EU countries are treated as a single unit reflect the harmonisation of corporate governance standards following the Single Market Programme. These variables control for the results reported in the previous section that returns in the short and long-run can vary by geographical region. Given that the US also accounts for the bulk of the acquisitions in our sample, we also run separate regressions on the US data alone.

The next three variables reflect the role of macroeconomic factors in determining acquisitions, specifically the role of the exchange rate and US tax reforms. If a depreciating currency overcomes capital market constraints (as suggested by Froot and Stein (op. cit.)) and US tax laws were biased in favour of domestic acquisitions prior to the 1986 Tax Reform Act (as suggested by Scholes and Wolfson (op. cit.)), we would expect these variables to have a negative sign.

$R \& D$ INT is intended to capture the ownership of firm-specific intangible assets and the role of internalisation which forms the basis of the OLI framework for explaining FDI as discussed in section 1. Reflecting the view that intangible assets may also be reflected in the nature of the product, we also include advertising expenditure as an indicator of intangible assets. Ideally, we would measure firm-specific R\&D and advertising expenditure. Unfortunately, such an analysis of the current sample is not possible as disclosure of $R \& D$ expenditure only became mandatory in the UK for accounting periods beginning on or after $1^{\text {st }}$ January 1989 (SSAP 13, revised), and unlike US GAAP, there is no requirement for UK firms to disclose expenditures on direct selling costs or advertising expenditures. Consequently, we have to rely on industry estimates. Preferably, we would use these for relevant years in our sample, 
but manufacturing industry figures for $R \& D$ intensity ( $R \& D$ as a percentage of sales) are only available from the Office of National Statistics from 1993 on. $^{17}$ We choose to use the final year of our sample period (1994) as a consequence, although in practice there appears to be little year-to-year variability in the industry level R\&D intensity. At present, no such data is produced for service industries, and to measure R\&D intensity here we constructed $R \& D /$ Sales for each industry using Datastream data. At present, no such data is produced for service industries. Advertising expenditure is more problematic, and only recently has any attempt been made to produce systematically researched data on UK advertising expenditure by industry as a percentage of sales. This data is only available from 1999 onwards and can be found in Paton and Conant (2000). We use these 1999 industry level advertising intensity measures as the proxy measure for advertising expenditure in our sample. If the internalisation hypothesis for FDI is to be substantiated, we would expect the R\&D and advertising intensity variables either independently or jointly to be statistically significant positive effect.

The final three variables are those that have been used to explain the distribution of abnormal returns in previous studies. To capture industry relatedness, we have a dummy variable reflecting whether the acquiring and target firm's main activity was in the same SIC. This data was available from Amdata. On the assumption that synergy may be important in value-enhancing acquisitions, we would expect this variable to have a positive impact on abnormal returns. HOSTILE notes whether the acquisition was subject to a hostile bid. This variable is included given the empirical evidence that "friendly" bids sometimes under-perform hostile bids (for a review of the relevant literature, see Agrawal and Jaffe, op. cit.). This variable therefore is expected to be positive. Finally, FORSALES represents the presence of the acquiring firm in the year prior to the acquisition. This is measured as the level of sales in the target country as a proportion of total sales of the acquiring firm. This variable was constructed using Datastream and the Multinational Yearbook ${ }^{18}$. Reflecting the

\footnotetext{
${ }^{17}$ Source: National Statistics. The authors are indebted to Jane Morgan of the Office for National Statistics, Cardiff, Wales, for her help in obtaining this data.

${ }^{18}$ Data could not be obtained for all firms in our data set. We therefore report the results for the full sample without this variable and with the smaller sample where we could retrieve data for this variable.
} 
previous literature on this issue (see discussion in section 1), the expected sign is negative.

We report the results for the event period returns for the full sample and then for the US sample separately with and without the FORSALES variable which, as noted above, not all data was available. We also do the same for the returns after 5 years. The results for the announcement period returns for all UK foreign acquisitions and for acquisitions in the US only are reported in Table 7. Consider, first of all, the results for the full sample excluding the FORSALES variable. The only variables that are statistically significant are the control dummy for acquisitions in the EU and the macroeconomic variables reflecting the exchange rate and US tax reforms. The negative sign on the EU dummy suggests lower abnormal returns relative to the Rest of the World though this is significant at only the 10 per cent level and becomes insignificant once the FORSALES variable is included. The role of macroeconomic factors tend to be the most important determinants of event period returns. The exchange rate has the expected negative sign and is significant at the 10 per cent level. However, when the FORSALES variable is included (column 3), the role of the exchange rate becomes statistically significant at the 5 per cent level. The role of US tax reforms also appears to be important being significant at the 5 per cent level in the full sample the negative sign being consistent with a priori expectations though it becomes insignificant in the smaller sample of firms. The role of factors reflecting the internalisation hypothesis have the correct signs but are not statistically significant as are the variables reflecting industry relatedness and the presence of hostile bidders. Industry relatedness does not appear to play a role in determining the short-run CAR results and neither does the existence of a hostile bidder. Compatible with the Doukas and Travlos (op. cit.) findings, FORSALES has a negative and significant coefficient.

Focussing on the US sample only, we find that the results are more or less identical with the exchange rate playing a more significant role being statistically significant at the 5 per cent level (see column 2) but being significant at the 1 per cent level when the FORSALES variable is included (column 4). US tax reform also remains important being significant at the 5 and 1 per cent levels respectively with and without the 
inclusion of the FORSALES variable. The results for the US sample also suggest some justification for the internalisation hypothesis, though in terms of advertising intensity rather than in the form of the $R \& D$ variable. The presence of the firm in the acquiring market (FORSALES) has the correct sign but is statistically significant at only the 10 per cent level. The inclusion of this variable is also important in that it improves the explanatory power of the regressions as a whole, in the case of the US sample increasing the adjusted $\mathrm{R}^{2}$ from 2 per cent to over 8 per cent.

Taken together, the results suggest that the role of macroeconomic factors appear to be the principal determinants of event period returns. This is consistent with other studies of cross-border acquisitions of Swanson (op. cit.) and Dewenter (op. cit.) and the theoretical work of Froot and Stein (op. cit.) and Scholes and Wolfson (op. cit.). The role of factors consistent with the traditional theory of FDI have only a limited role while factors commonly referred to in the finance literature have no significant effect with the exception of the variable reflecting presence in the target market.

\section{Table 7 here}

The results of the regressions of 5-year abnormal returns are reported in Table 8. Referring to the full sample first of all (columns 1 and 3), it should be noted that the role of the exchange rate and the tax reform variables stand in marked contrast to the event period returns as neither of these variables are statistically significant at acceptable levels. This is true whether we consider the larger sample excluding the FORSALES variable or the smaller sample with its inclusion. Note however the role of the R\&D variable, this variable being statistically significant at the 1 per cent level in both the larger and smaller samples. When the FORSALES variable is included, this variable is statistically significant at the 5 per cent level and has the expected negative sign while the variable reflecting a hostile bid is significant at the 1 per cent level and has the anticipated sign. Note also that the overall explanatory power of the regression increases following the inclusion of the FORSALES variable.

The US sample reinforces these results. The exchange rate is of no importance with only weak evidence for the role of the tax policy reforms. The internalisation 
hypothesis continues to receive strong support with the $R \& D$ variable continuing to be highly significant, as is the advertising intensity variable when the FORSALES variable is included. Although this variable is not statistically significant in the US sample, its inclusion leads to the impact of a hostile bid having a positive effect on long-run returns which is statistically significant at the 1 per cent level. Note also that the adjusted $\mathrm{R}^{2}$ increases to around 20 per cent in the FORSALES included sample.

\section{Table 8 here}

The significance of the results reported in tables 7 and 8 is that the factors that determine the distribution of abnormal returns appear to change as we move from the event period returns to returns 5 years post-acquisition. Specifically, the role of ownership factors such as R\&D which have played a prominent role in the FDI literature have, at the very most, only limited explanatory power in determining the event period returns of UK acquiring firms. Rather, the role of short-term macroeconomic and policy factors such as the exchange rate and tax reforms have a dominating influence. In contrast, in considering the returns 5 years post-acquisition, these factors diminish in their importance in determining the distribution of returns. However, unlike the event period sample, the role of factors reflecting the internalisation hypothesis become the most important influences. As such, the significance of these results would appear to suggest that the market inappropriately values cross-border acquisitions in the short-run with those firms doing well in the longer-run being those with a strong intangible asset (mainly R\&D) base, consistent with the traditional literature on FDI.

\section{Conclusions}

The back-drop to this paper has been the dramatic surge in FDI that has occurred in the world economy since the mid-1980s and has involved, in the main, cross-border acquisitions. The specific aim of this paper has been to consider the performance of acquiring firms from the event date through to the end of a 5-year period. Using a near-exhaustive sample of significant UK acquisitions abroad the results indicate significant negative abnormal returns to firms acquiring in the US, returns to firms acquiring in the EU being not significantly different from zero, whilst those relatively 
few takeovers in the rest of the world appear to exhibit performance which is positive and statistically significant. The results further indicate that investing in a related industry also has a negative impact on the returns achieved. Returns to acquirers do not appear to be explained to any significant degree by "glamour" versus "value” firm effects. These results differ from abnormal returns estimated around the event date that has been the focus on previous literature on foreign acquisitions. On the whole, the results for the full sample, irrespective of any specific country or region, show that returns around the event date are not statistically significant from zero. The reversal in fortune for UK firms acquiring targets in the US is one of the key results in this paper and reflects that geographical variation in returns may reflect similarities or differences in legal and corporate governance standards throughout the world. Alternatively, given the similarity in corporate governance between the UK and US, the negative returns in the US may reflect the intensity of short-run competition for US targets due to the depreciating dollar and US tax reforms that lead to a significant increase in foreign acquisitions, but that these short-run factors did not fully disclose value-creating acquisitions that would only become apparent in the longer-run.

We have explored the possible reasons for explaining the variation in the performance of UK acquirers over both the sort and long-run. The most interesting results relate to the observation that the factors that appear to determine the distribution of event period returns differ from those that determine returns after 5 years. Specifically, the role of the exchange rate and US tax reforms have an important role in determining event period returns though these factors have at most a limited impact in explaining returns 5 years post-acquisition. In contrast, while R\&D plays no statistically significant role in the short-run, it becomes the most important factor explaining longer run returns. The latter result is entirely consistent with the internalisation hypothesis. Reflecting the difference between the event period and longer run abnormal returns, the factors that determine the returns over this longer-run period are markedly different from those determining event period returns. The implication of this is that acquiring firms with specific advantages will likely return a stronger postacquisition performance even if event period, time-specific determining factors dissipate over the longer-run. In sum, these results generate some sources of concern in the way that markets value cross-border acquisitions with commensurate 
implications for shareholder wealth in that long-run returns can differ from announcement period returns as can the factors which seem to be important in determining longer run returns.

\section{REFERENCES:}

Agrawal, A., Jaffe, J.F. and Mandelker, G.N. (1992), 'The Post-Merger Performance of Acquiring Firms; A Re-Examination of an Anomaly', Journal of Finance, 47, 1605-22.

Agrawal, A., and Jaffe, F.E. (2000), 'The post merger performance puzzle', in Advances in Mergers and Acquisitions, Cooper, C. and Gregory, A. (eds.), JAI Press, New York.

Barber, B.M. and J.D. Lyon (1997), "Detecting Long-Run Abnormal Stock Returns: The Empirical Power and Specification of Test Statistics", Journal of Financial Economics, 43, 341-372. 
Blonigen, B. (1997) 'Firm-Specific Assets and the Link Between Exchange Rates and Foreign Direct Investment' American Economic Review, 87, 447-465.

Brown, S. and J.B. Warner (1980), “Measuring Security Price Performance”, Journal of Financial Economics, 8, 205-258.

Cakici, N. C. Hessel and K. Tandon (1996) 'Foreign Acquisitions in the United States: Effect on Shareholder Wealth of Foreign Acquiring Firms' Journal of Banking and Finance, 20, 307-329.

Chistopherson, J.A., Ferson, W.E. and Glassman, D.E.. (1996), "Conditioning Manager Alphas on Economic Information: Another Look at the Persistence of Performance”, National Bureau of Economic Research, Working Paper 5830

Conn, R.C., and Connell, F. (1990), 'International Mergers; Returns to US and British Firms’, Journal of Business Finance and Accounting, Winter 1990, 689-711.

Conn, C., Cosh, A., Guest, P. and Hughes, A. (2001), 'Long-Run Share Performance of UK Firms Engaging in Cross-Border Acquisitions', University of Cambridge, Working paper WP 214.

Corhay, A. and A.T. Rad (2000) 'International Acquisitions and Shareholder Wealth: Evidence from the Netherlands' International Review of Financial Analysis, 164-174.

Datta, D.K. and G. Puia (1995) 'Cross-Border Acquisitions: An Examination of the Influence of Related and Cultural Fit on Shareholder Value Creation in US Acquiring Firms' Management International Review, 35, 337-359.

Dewenter, K.L. (1995a), 'Do Exchange Rate Changes Drive Foreign Direct Investment?’ Journal of Business, 68, 405-433.

Dewenter, K.L. (1995b), 'Does the Market React Differently to Domestic and Foreign Takeover Announcements? Evidence from US Chemical and Retail Industries,' Journal of Financial Economics, 37, 421-441.

Doukas, J. and N.G. Travlos (1988), 'The Effect of Corporate Multinationalism on Shareholders' Wealth: Evidence from International Acquisitions'. Journal of Finance, 43, 401-417.

Dunning, J.H. (1993), The Globalisation of Business. London, Routledge.

Eun, C.S., R. Kolodny and C. Scheraga (1996), 'Cross-border Acquisitions and Shareholder Wealth: Tests of the Synergy and Internalisation Hypothesis'. Journal of Banking and Finance, 20, 1559-1582.

Fama, E.F. and French, K.R. (1993), 'Common Risk Factors in Returns on Stocks and Bonds', Journal of Financial Economics, 33, 3-56. 
Fama, E. and K. French. (1995), "Size and Book-to-Market Factors in Earnings and Returns”, Journal of Finance, L, 1 (March), 131-155.

Fama, E.F. and French, K.R. (1996), 'Multifactor Explanations of Asset Pricing Anomalies', Journal of Finance, 50, 131-155.

Fatemi, A. and E.P. Furtado (1988) 'An Empirical Investigation of the Wealth Effects of Foreign Acquisitions' in S. Kouri and A. Ghosh (eds) Recent Developments in International Banking and Finance (vol.2) Lexington MA, Lexington Books

Ferson, W.E. and Schadt, R.W. (1996), "Measuring Fund Strategy and Performance in Changing Economic Conditions”, Journal of Finance, 51:2, June, 425-61.

Froot, K. A. and J.C. Stein (1991) 'Exchange Rates and Foreign Direct Investment: An Imperfect Capital Markets Approach' Quarterly Journal of Economics, 106, 1191-1217.

Harris, R.S. and D. Ravenscraft (1991) 'The Role of Acquisitions in Foreign Direct Investment: Evidence from the US Stock Market' Journal of Finance, 46, 825824.

Gregory, A. (1997), 'An Examination of the Long Run Performance of UK Acquiring Firms’, Journal of Business Finance and Accounting, 24 (7\&8), 971-1002.

Gregory, A., Harris, R.D.F. and Michou, M., (2001) 'An Analysis of Contrarian Investment Strategies in the UK' Journal of Business Finance and Accounting, Vol. 28/9\&10, 11931-1228.

Healy, P.M. and K. G. Palepu (1993), 'International Corporate Equity Acquisitions: Who, Where and Why?' in K.A.Froot (ed.) Foreign Direct Investment. University of Chicago Press. Chicago.

Ikenberry, D., J. Lakonishok and T. Vermaelen (1995) 'Market Under-Reaction to Open Market Share Repurchases' Journal of Financial Economics, 39, 181-208.

Kang, J-K. (1993), ' The International Market for Corporate Control', Journal of Financial Economics, 34, 345-371.

Kothari, S.P. and J.B. Warner (1997), "Measuring Long-Horizon Security Price Performance”, Journal of Financial Economics, 43, 301-339.

La Porta, R. F. Loez-de-Silanes, A. Schleifer and R. Vishny (2000) 'Investor Protection and Corporate Governance' Journal of Financial Economics, 58, 328.

La Porta, R. F. Loez-de-Silanes, A. Schleifer and R. Vishny (2001) 'Law and Finance' Journal of Political Economy, 106, 1113-1155. 
Loughran, T. and A.M.Vijh (1997) 'Do Long-Term Shareholders Benefit from Corporate Acquisitions?' Journal of Finance, 52, 1765-1790.

Lyon, J. Barber, B. and C.-L. Tsai (1999) "Improved Methods for Tests of Long-Run Abnormal Stock Returns”, Journal of Finance, 54(1), February, 165-201.

Moeller, S. R., F. P. Schlingemann and R. M. Stultz (2003) 'Do Shareholders of Acquiring Firms Gain from Acquisitions?’ NBER Working Paper No. 9523. Cambridge MA.

Morck, R. and B. Yeung (1992), 'Internalization: An Event Study', Journal of International Economics, 33, 41-56.

Paton, D., and Conant, N. (2000) An Introduction to the 1999 Advertising and Industry Survey. Nottingham University Business School

Rau, P.R. and Vermaelen, T. (1998), 'Glamour, Value and the Post-Acquisition Performance of Acquiring Firms', Journal of Financial Economics, 49, 223253.

Roll, R. (1986), 'The Hubris Hypothesis of Corporate Takeovers', Journal of Business, 59 (2), 197-216.

Rossi, S. and P. Volpin (2003) 'Cross-Country Determinants of Mergers and Acquisitions’ CEPR Discussion Paper No. 3889. London.

Scholes, M. S. and M.A. Wolfson (1990) 'The Effects of Changes in Tax Laws on Corporate Reorganisation Activity' Journal of Business, 63, S141-164.

Strong, N. and Xu (1992), 'Modelling Abnormal Returns: A Review Article', Journal of Business Finance and Accounting, June, 533-553.

Swenson, D.L. (1993), 'Foreign Mergers and Acquisitions in the United States' in K.A. Froot (ed.) Foreign Direct Investment. University of Chicago Press. Chicago.

UNCTAD (2000) World Investment Report 2000: Cross-Border Mergers and Acquisitions and Development. UNCTAD, Geneva.

White, H. (1980), 'A Heteroscedasticity-Consistent Covariance Matrix Estimator and a Direct Test for Heteroscedasticity’, Econometrica, Vol. 48, 1980, 817838. 
Table 1: Characteristics of Sample of UK Foreign Acquisitions: 1984-1995

\begin{tabular}{|l|l|l|c|c|c|c|}
\hline Year & Acquisitions in: & US & EU & Rest of World & Same Industry & $\begin{array}{c}\text { Conglomerate } \\
\text { Acquisitions }\end{array}$ \\
\hline 1984 & & 4 & 0 & 0 & 2 & 2 \\
\hline 1985 & & 4 & 1 & 0 & 4 & 1 \\
\hline 1986 & & 27 & 1 & 0 & 20 & 8 \\
\hline 1987 & & 25 & 3 & 3 & 19 & 12 \\
\hline 1988 & & 39 & 16 & 7 & 42 & 20 \\
\hline 1989 & & 26 & 8 & 5 & 23 & 16 \\
\hline 1990 & & 20 & 15 & 1 & 24 & 12 \\
\hline 1991 & & 12 & 9 & 5 & 20 & 6 \\
\hline 1992 & & 11 & 11 & 3 & 18 & 7 \\
\hline 1993 & & 20 & 14 & 7 & 27 & 14 \\
\hline 1994 & & 18 & 20 & 8 & 37 & 9 \\
\hline Total & & 206 & 98 & 39 & 238 & 105 \\
\hline
\end{tabular}

Source of sample data is Amdata. Note that the data for 1984 is from October 1984 onwards.

Same industry acquisitions was defined according to acquisitions within the same Standard Industrial

Trade Classification at the 2 digit level. All other acquisitions were regarded as conglomerate acquisitions.

Table 2:Short-run CAR Results for UK Acquiring Firms 


\begin{tabular}{|c|c|c|c|c|c|c|}
\hline & All Countries & US Acquisitions & EU Acquisitions & RoW Acquisitions & $\begin{array}{l}\text { All Countries: } \\
\text { Same SIC }\end{array}$ & $\begin{array}{l}\text { All Countries: } \\
\text { Conglomerate }\end{array}$ \\
\hline Average CAR & -0.00022 & 0.002372 & -0.00719 & 0.002026 & -0.00134 & 0.00168 \\
\hline Standard Deviation & 0.06001 & 0.062565 & 0.062173 & 0.036879 & 0.064688 & 0.048698 \\
\hline T-test & -0.068328 & 0.544091 & -1.14431 & 0.343049 & -0.31848 & 0.356902 \\
\hline Sample Size & 333 & 206 & 98 & 39 & 236 & 107 \\
\hline
\end{tabular}

The CAR results are the cumulative abnormal returns of the acquirer's stock price over a $(-3,1)$ event window around the announcement date. 
Table 3: Overall results for foreign acquisitions by UK companies. Figures shown are the abnormal returns for 1-year, 3-year and 5-year post acquisition returns together with the Lyon et al (1999) bootstrapped skewness-adjusted t-statistic, critical values of the statistic based upon its empirical distribution from bootstrapped resamples, and empirical $p$ values for the from the distribution of sample means from Lyon et al style pseudo-portfolios. Significant observations at the $1 \%$, $5 \%$ and $10 \%$ levels for both tests are shown by $* * *, * *$ and * respectively, whilst $n s$ denotes the observed abnormal returns are not significantly different from zero. The last two rows in the table show the breakdown of the observations by book-to-market quintile, with the significance level shown respectively for the bootstrapped skewness-adjusted $t$ statistic, and the empirical $p$ values from the pseudo-portfolios.

\begin{tabular}{|c|c|c|c|c|c|c|c|c|c|c|}
\hline Years post takeover & $\begin{array}{l}\text { Abnormal } \\
\text { return }\end{array}$ & \begin{tabular}{|l} 
Bootstrapped \\
skewness- \\
adjusted t- \\
statistic
\end{tabular} & \begin{tabular}{|l|} 
Critical \\
value for \\
$10 \%$ \\
significance \\
\end{tabular} & \begin{tabular}{|l|} 
Critical \\
value for \\
$5 \%$ \\
significance
\end{tabular} & \begin{tabular}{|l|} 
Critical \\
value for \\
$1 \%$ \\
significance
\end{tabular} & \begin{tabular}{|l|} 
Significance \\
of \\
bootstrapped \\
skewness- \\
adjusted t- \\
statistic \\
\end{tabular} & \begin{tabular}{|l|} 
Pseudo- \\
portfolio \\
critical \\
value for \\
$10 \%$ \\
significance \\
\end{tabular} & \begin{tabular}{|l|} 
Pseudo- \\
portfolio \\
critical \\
value for \\
$5 \%$ \\
significance \\
\end{tabular} & \begin{tabular}{|l|} 
Pseudo- \\
portfolio \\
critical \\
value for \\
$1 \%$ \\
significance \\
\end{tabular} & \begin{tabular}{|l|} 
Significance \\
from \\
empirical \\
pseudo \\
portfolio \\
distribution \\
\end{tabular} \\
\hline 1 year abnormal return & 0.0065 & 0.4619 & -1.3696 & -1.6365 & -2.1770 & $\mathrm{~ns}$ & -0.0306 & -0.0352 & -0.0442 & ns \\
\hline 3 year abnormal return & -0.0390 & -1.0612 & -1.5280 & -1.9562 & -2.5132 & ns & -0.0610 & -0.0728 & -0.0910 & ns \\
\hline 5 year abnormal return & -0.0929 & -0.6127 & -2.1705 & -2.5671 & -3.4359 & ns & -0.1058 & -0.1189 & -0.1551 & ns \\
\hline
\end{tabular}

Breakdown of 5-year returns by BTM

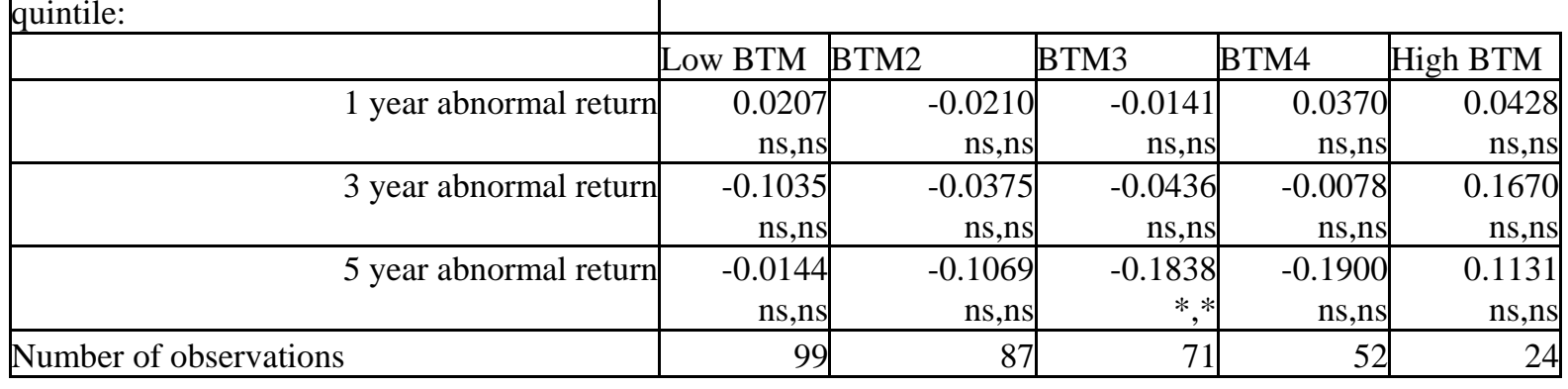


Table 4: Abnormal returns for foreign acquisitions by UK companies by region. Figures shown are the abnormal returns for 1-year, 3-year and 5-year post acquisition returns together with the Lyon et al (1999) bootstrapped skewness-adjusted t-statistic, critical values of the statistic based upon its empirical distribution from bootstrapped resamples, and empirical $p$ values for the from the distribution of sample means from Lyon et al style pseudo-portfolios. Significant observations at the $1 \%$, $5 \%$ and $10 \%$ levels for both tests are shown by ***, ** and * respectively, whilst $n s$ denotes the observed abnormal returns are not significantly different from zero.

\begin{tabular}{|c|c|c|c|c|c|c|c|c|c|c|}
\hline $\begin{array}{l}\text { Years post } \\
\text { takeover }\end{array}$ & $\begin{array}{l}\text { Abnormal } \\
\text { return }\end{array}$ & $\begin{array}{l}\text { Bootstrapped } \\
\text { skewness-adjusted } \\
\text { t-statistic }\end{array}$ & $\begin{array}{l}\text { Critical value } \\
\text { for } 10 \% \\
\text { significance } \\
\end{array}$ & \begin{tabular}{|l|} 
Critical value \\
for $5 \%$ \\
significance
\end{tabular} & \begin{tabular}{|l} 
Critical value \\
for $1 \%$ \\
significance
\end{tabular} & $\begin{array}{l}\text { Significance of } \\
\text { bootstrapped } \\
\text { skewness- } \\
\text { adjusted t- } \\
\text { statistic } \\
\end{array}$ & $\begin{array}{l}\text { Pseudo- } \\
\text { portfolio } \\
\text { critical value } \\
\text { for } 10 \% \\
\text { significance } \\
\end{array}$ & \begin{tabular}{|l|} 
Pseudo- \\
portfolio \\
critical value \\
for 5\% \\
significance \\
\end{tabular} & \begin{tabular}{|l|} 
Pseudo- \\
portfolio \\
critical value \\
for $1 \%$ \\
significance \\
\end{tabular} & $\begin{array}{l}\text { Significance } \\
\text { from empirical } \\
\text { pseudo } \\
\text { portfolio } \\
\text { distribution } \\
\end{array}$ \\
\hline US results & $n=197$ & & & & & & & & & \\
\hline \begin{tabular}{|r|}
1 year abnormal \\
return
\end{tabular} & 0.0019 & 0.1148 & -1.5368 & -1.9075 & -2.5738 & & -0.0367 & -0.0431 & -0.0548 & Bns \\
\hline \begin{tabular}{|r|}
3 year abnormal \\
return
\end{tabular} & -0.0936 & -2.2464 & -1.6109 & -2.0280 & $-2.5307=$ & $* *$ & -0.0783 & -0.0944 & -0.1146 & $*$ \\
\hline \begin{tabular}{|r|}
5 year abnormal \\
return
\end{tabular} & -0.2709 & -4.0544 & -1.5099 & -1.7187 & -2.2834 & $* * *$ & -0.1157 & -0.1375 & -0.1886 & *** \\
\hline EU results & $n=97$ & & & & & & & & & \\
\hline \begin{tabular}{|r|}
1 year abnormal \\
return
\end{tabular} & -0.0035 & -0.1193 & -1.6480 & -2.0312 & -2.9813 & & -0.0492 & -0.0572 & -0.0748 & ns \\
\hline \begin{tabular}{|r|}
3 year abnormal \\
return \\
\end{tabular} & -0.0296 & -0.3589 & -1.6384 & -1.9119 & -2.4518 & & -0.1134 & -0.1308 & -0.1735 & ns \\
\hline \begin{tabular}{|r|}
5 year abnormal \\
return
\end{tabular} & 0.1020 & 0.4861 & -3.0443 & -3.4276 & -4.2410 & & -0.2123 & -0.2359 & -0.2990 & ns \\
\hline ROW results & $n=39$ & & & & & & & & & \\
\hline \begin{tabular}{|r|}
1 \\
1 year abnormal \\
return
\end{tabular} & 0.054744 & 1.203149 & -1.5987 & -1.84908 & -2.47839 & & -0.06765 & -0.07839 & -0.09263 & ns \\
\hline \begin{tabular}{|r|}
3 year abnormal \\
return
\end{tabular} & 0.213079 & 2.035417 & -2.0383 & -2.69034 & $-3.57181=$ & ** positive & -0.14794 & -0.18165 & -0.23845 & **positive \\
\hline \begin{tabular}{|r|}
5 year abnormal \\
return
\end{tabular} & 0.321452 & 1.412187 & -2.51806 & -3.50777 & $-5.64105=$ & *positive & -0.25607 & -0.31374 & -0.38622 & *positive \\
\hline
\end{tabular}


Table 5: Abnormal returns for foreign acquisitions by UK companies by 2-digit SIC diversity of acquisition. Figures shown are the abnormal returns for 1-year, 3year and 5-year post acquisition returns together with the Lyon et al (1999) bootstrapped skewness-adjusted t-statistic, critical values of the statistic based upon its empirical distribution from bootstrapped resamples, and empirical $p$ values for the from the distribution of sample means from Lyon et al style pseudo-portfolios. Significant observations at the $1 \%, 5 \%$ and $10 \%$ levels for both tests are shown by $* * *, * *$ and * respectively, whilst $n s$ denotes the observed abnormal returns are not significantly different from zero.

\begin{tabular}{|c|c|c|c|c|c|c|c|c|c|c|}
\hline Years post takeover & $\begin{array}{l}\text { Abnormal } \\
\text { return }\end{array}$ & \begin{tabular}{|l|} 
Bootstrapped \\
skewness- \\
adjusted t- \\
statistic
\end{tabular} & $\begin{array}{l}\text { Critical value } \\
\text { for } 10 \% \\
\text { significance }\end{array}$ & $\begin{array}{l}\text { Critical value } \\
\text { for } 5 \% \\
\text { significance }\end{array}$ & $\begin{array}{l}\text { Critical value } \\
\text { for } 1 \% \\
\text { significance }\end{array}$ & \begin{tabular}{|l|} 
Significance of \\
bootstrapped \\
skewness- \\
adjusted t- \\
statistic
\end{tabular} & $\begin{array}{l}\text { Pseudo- } \\
\text { portfolio } \\
\text { critical value } \\
\text { for } 10 \% \\
\text { significance }\end{array}$ & $\begin{array}{l}\text { Pseudo- } \\
\text { portfolio } \\
\text { critical value } \\
\text { for 5\% } \\
\text { significance }\end{array}$ & $\begin{array}{l}\text { Pseudo- } \\
\text { portfolio } \\
\text { critical value } \\
\text { for } 1 \% \\
\text { significance }\end{array}$ & \begin{tabular}{|l|} 
Significance \\
from empirical \\
pseudo \\
portfolio \\
distribution \\
\end{tabular} \\
\hline Same SIC & $n=229$ & & & & & & & & & \\
\hline \begin{tabular}{|l|}
1 year abnormal return \\
\end{tabular} & 0.022976 & 1.317197 & -1.41283 & -1.6551 & -2.18138 & ns & -0.03349 & -0.0403 & -0.05785 & ns \\
\hline 3 year abnormal return & -0.04048 & -0.86107 & -1.67213 & -2.10007 & -2.7313 & $\mathrm{~ns}$ & -0.07771 & -0.09015 & -0.11473 & ns \\
\hline 5 year abnormal return & -0.03589 & -0.11376 & -2.55749 & -2.9928 & -3.77766 & ns & -0.12334 & -0.1493 & -0.1953 & 4 ns \\
\hline Diff SIC & $n=104$ & & & & & & & & & \\
\hline 1 year abnormal return & -0.02967 & -1.24796 & -1.66624 & -2.00867 & -2.63083 & $\mathrm{~ns}$ & -0.04975 & -0.05686 & -0.06899 & ns \\
\hline 3 year abnormal return & -0.03588 & -0.61579 & -1.65052 & -1.91585 & -2.5706 & ns & -0.09231 & -0.10804 & -0.1298 & 4 ns \\
\hline 5 year abnormal return & -0.21849 & -2.34291 & -1.50655 & -1.80751 & -2.69736 & $* *$ & -0.16 & -0.18655 & -0.2304 & $4 *$ \\
\hline
\end{tabular}


Table 6: Abnormal returns for US acquisitions by UK companies by 2-digit SIC diversity of acquisition and BTM quintile. Figures shown are the abnormal returns for 1-year, 3-year and 5-year post acquisition returns together with the Lyon et al (1999) bootstrapped skewness-adjusted t-statistic, critical values of the statistic based upon its empirical distribution from bootstrapped resamples, and empirical $p$ values for the from the distribution of sample means from Lyon et al style pseudo-portfolios. Significant observations at the $1 \%, 5 \%$ and $10 \%$ levels for both tests are shown by $* * *, * *$ and $*$ respectively, whilst $n s$ denotes the observed abnormal returns are not significantly different from zero. The last two rows in the table show the breakdown of the observations by book-to-market quintile, with the significance level shown respectively for the bootstrapped skewness-adjusted $t$-statistic, and the empirical $p$ values from the pseudo-portfolios.

\begin{tabular}{|c|c|c|c|c|c|c|c|c|c|c|}
\hline Years post takeover & $\begin{array}{l}\text { Abnormal } \\
\text { return }\end{array}$ & $\begin{array}{l}\text { Bootstrapped } \\
\text { skewness- } \\
\text { adjusted t- } \\
\text { statistic }\end{array}$ & \begin{tabular}{|l|} 
Critical \\
value for \\
$10 \%$ \\
significance \\
\end{tabular} & $\begin{array}{l}\text { Critical } \\
\text { value for } 5 \% \\
\text { significance }\end{array}$ & \begin{tabular}{|l|} 
Critical \\
value for 1\% \\
significance \\
\end{tabular} & $\begin{array}{l}\text { Significance } \\
\text { of } \\
\text { bootstrapped } \\
\text { skewness- } \\
\text { adjusted t- } \\
\text { statistic }\end{array}$ & \begin{tabular}{|l|} 
Pseudo- \\
portfolio \\
critical value \\
for $10 \%$ \\
significance \\
\end{tabular} & \begin{tabular}{|l|} 
Pseudo- \\
portfolio \\
critical value \\
for $5 \%$ \\
significance
\end{tabular} & $\begin{array}{l}\text { Pseudo- } \\
\text { portfolio } \\
\text { critical value } \\
\text { for } 1 \% \\
\text { significance }\end{array}$ & $\begin{array}{l}\text { Significance } \\
\text { from } \\
\text { empirical } \\
\text { eseudo } \\
\text { portfolio } \\
\text { distribution }\end{array}$ \\
\hline Same SIC & $n=128$ & & & & & & & & & \\
\hline 1 year abnormal return & 0.026707 & 1.266533 & -1.44009 & -1.84985 & -2.48045 & ns & -0.05079 & -0.05738 & -0.06598 & $8 \mathrm{~ns}$ \\
\hline 3 year abnormal return & -0.11016 & -2.21619 & -1.46589 & -1.66224 & -2.29607 & $* *$ & -0.0942 & -0.10586 & -0.12439 & $9 * *$ \\
\hline 5 year abnormal return & -0.29571 & -3.62854 & -1.52596 & -1.95725 & -2.53479 & $* * *$ & -0.1691 & -0.19006 & -0.25815 & $5 * * *$ \\
\hline Diff SIC & $n=69$ & & & & & & & & & \\
\hline 1 year abnormal return & -0.04408 & -1.45588 & -1.6892 & -2.00878 & -2.67874 & ns & -0.05325 & -0.06045 & -0.07578 & $8 \mathrm{~ns}$ \\
\hline 3 year abnormal return & -0.06295 & -0.83608 & -1.7787 & -2.18104 & -3.66527 & ns & -0.11251 & -0.13416 & -0.15826 & $6 \mathrm{~ns}$ \\
\hline 5 year abnormal return & -0.22495 & -1.93632 & -1.8948 & -2.26695 & -3.30803 & & -0.18286 & -0.20624 & -0.27108 & $8 * *$ \\
\hline
\end{tabular}

Breakdown of 5-year returns by BTM

quintile:

\begin{tabular}{|r|r|r|r|r|r|}
\hline & Low BTM & BTM2 & BTM3 & BTM4 & High BTM \\
\hline 1 year abnormal return & -0.0027 & -0.0213 & 0.0148 & 0.0386 & -0.0465 \\
& $\mathrm{~ns}, \mathrm{~ns}$ & $\mathrm{~ns}, \mathrm{~ns}$ & $\mathrm{~ns}, \mathrm{~ns}$ & $\mathrm{~ns}, \mathrm{~ns}$ & $\mathrm{~ns}, \mathrm{~ns}$ \\
\hline 3 year abnormal return & -0.1844 & -0.0833 & -0.0042 & -0.0439 & -0.1217 \\
& $* *, *$ & $\mathrm{~ns}, \mathrm{~ns}$ & $\mathrm{~ns}, \mathrm{~ns}$ & $\mathrm{~ns}, \mathrm{~ns}$ & $\mathrm{~ns}, \mathrm{~ns}$ \\
\hline 5 year abnormal return & -0.4523 & -0.0976 & -0.1294 & -0.3561 & -0.2583 \\
& $* * *, * * * *$ & $\mathrm{~ns}, \mathrm{~ns}$ & $\mathrm{~ns}, \mathrm{~ns}$ & $* *, * *$ & $\mathrm{~ns}, \mathrm{~ns}$ \\
\hline Number of observations & 64 & 48 & 43 & 34 & 8 \\
\hline
\end{tabular}


Table 7. Regression Tests of Determinants of Event Period Returns

Dependent variables are the standardised event period CARs. For an explanation of the independent variables see text. The figures in italics under the coefficients are $p$-values from a two-tailed test

\begin{tabular}{|c|c|c|c|c|}
\hline $\begin{array}{l}\text { INDEPENDENT } \\
\text { VARIABLE }\end{array}$ & $\begin{array}{l}\text { FULL } \\
\text { SAMPLE }\end{array}$ & US SAMPLE & $\begin{array}{l}\text { FULL } \\
\text { SAMPLE }\end{array}$ & US SAMPLE \\
\hline CONSTANT & $\begin{array}{l}0.594 \\
(0.8401)\end{array}$ & $\begin{array}{l}-0.1005 \\
(-0.1510)\end{array}$ & $\begin{array}{l}1.0419 \\
(1.069)\end{array}$ & $\begin{array}{l}0.0238 \\
(0.0198)\end{array}$ \\
\hline US & $\begin{array}{l}-0.253 \\
(-0.3663)\end{array}$ & & $\begin{array}{l}-0.2686 \\
(-0.2944)\end{array}$ & \\
\hline $\mathbf{E U}$ & $\begin{array}{l}-1.0621^{* * *} \\
(-1.657)\end{array}$ & & $\begin{array}{l}-1.1409 \\
(-1.397)\end{array}$ & \\
\hline EXRATE & $\begin{array}{l}-6.2425^{* * *} \\
(-1.876)\end{array}$ & $\begin{array}{l}-13.873^{* *} \\
(-2.185)\end{array}$ & $\begin{array}{l}-9.4942^{* *} \\
(-2.049)\end{array}$ & $\begin{array}{l}-24.437^{*} \\
(-2.652)\end{array}$ \\
\hline US TAX & $\begin{array}{l}-2.4414^{* *} \\
(-2.366)\end{array}$ & $\begin{array}{l}-3.6168^{*} \\
(-2.778)\end{array}$ & $\begin{array}{l}-2.7242 \\
(-1.284)\end{array}$ & $\begin{array}{l}-4.7768^{* *} \\
(-1.997)\end{array}$ \\
\hline R\&D INT & $\begin{array}{l}0.0388 \\
(1.053)\end{array}$ & $\begin{array}{l}0.02557 \\
(0.5823)\end{array}$ & $\begin{array}{l}0.0594 \\
(1.344)\end{array}$ & $\begin{array}{l}0.0725 \\
(1.233)\end{array}$ \\
\hline ADV INT & $\begin{array}{l}0.288 \\
(0.9913)\end{array}$ & $\begin{array}{l}0.7083^{* * *} \\
(1.745)\end{array}$ & $\begin{array}{l}0.3998 \\
(1.016)\end{array}$ & $\begin{array}{l}1.1904^{* *} \\
(1.991)\end{array}$ \\
\hline SAME SIC & $\begin{array}{l}-0.5389 \\
(-1.102)\end{array}$ & $\begin{array}{l}-0.3489 \\
(-0.5103)\end{array}$ & $\begin{array}{l}-0.9634 \\
(-1.449)\end{array}$ & $\begin{array}{l}-1.965 \\
(-1-131)\end{array}$ \\
\hline HOSTILE & $\begin{array}{l}-0.5069 \\
(-0.3877)\end{array}$ & $\begin{array}{l}-0.1313 \\
(-0.1016)\end{array}$ & $\begin{array}{l}0.7931 \\
(0.4751)\end{array}$ & $\begin{array}{l}2.026 \\
(1.162)\end{array}$ \\
\hline FOR.SALES & & & $\begin{array}{l}-3.145^{* *} \\
(-2.003)\end{array}$ & $\begin{array}{l}-3.6095^{* * *} \\
(-1.698)\end{array}$ \\
\hline$\underset{\text { SAMPLE SIZE }}{\operatorname{ADJUSTED} \mathbf{R}^{2}}$ & $\begin{array}{l}0.0119 \\
328\end{array}$ & $\begin{array}{l}0.0365 \\
193\end{array}$ & $\begin{array}{l}0.0207 \\
224\end{array}$ & $\begin{array}{l}0.0853 \\
124\end{array}$ \\
\hline
\end{tabular}

Numbers in parantheses are t-statistics. * represents significance at the 1 per cent level, ** represents significance at the 5 per cent level and $* * *$ represents significance at the 10 per cent level. 
Table 8. Regression Tests of Determinants of Long-Run Returns

Dependent variables are the 60-month standardised CARs from the Fama-French 3-factor model. For an explanation of the independent variables see text. The figures in italics under the coefficients are $p$ values from a two-tailed test

\begin{tabular}{|c|c|c|c|c|}
\hline $\begin{array}{l}\text { INDEPENDENT } \\
\text { VARIABLE }\end{array}$ & $\begin{array}{l}\text { FULL } \\
\text { SAMPLE }\end{array}$ & US SAMPLE & $\begin{array}{l}\text { FULL } \\
\text { SAMPLE }\end{array}$ & US SAMPLE \\
\hline CONSTANT & $\begin{array}{l}0.10388 \\
(0.4248)\end{array}$ & $\begin{array}{l}-0.0951 \\
(-0.5263)\end{array}$ & $\begin{array}{l}0.2948 \\
(1.003)\end{array}$ & $\begin{array}{l}-0.5521 * \\
(-2.84)\end{array}$ \\
\hline US & $\begin{array}{l}-0.1373 \\
(-0.6497)\end{array}$ & & $\begin{array}{l}-0.3172 \\
(-1.350)\end{array}$ & \\
\hline EU & $\begin{array}{l}-0.1056 \\
(-0.4500)\end{array}$ & & $\begin{array}{l}-0.2423 \\
(-0.9098)\end{array}$ & \\
\hline SAME SIC & $\begin{array}{l}-0.0341 \\
(-0.2662)\end{array}$ & $\begin{array}{l}-0.0409 \\
(-0.277)\end{array}$ & $\begin{array}{l}0.0504 \\
(0.3376)\end{array}$ & $\begin{array}{l}-0-.6747 \\
(-0.4146)\end{array}$ \\
\hline EXRATE & $\begin{array}{l}0.4394 \\
(1.090)\end{array}$ & $\begin{array}{l}-0.2844 \\
(-0.5697)\end{array}$ & $\begin{array}{l}0.6053 \\
(1.232)\end{array}$ & $\begin{array}{l}-0.3066 \\
(-0.4209)\end{array}$ \\
\hline US TAX & $\begin{array}{l}-0.063 \\
(-0.2874)\end{array}$ & $\begin{array}{l}0.1795 \\
(0.779)\end{array}$ & $\begin{array}{l}0.1853 \\
(0.6424)\end{array}$ & $\begin{array}{l}0.6043^{* * *} \\
(1.724)\end{array}$ \\
\hline R\&D INT & $\begin{array}{l}0.03468^{*} \\
(4.977)\end{array}$ & $\begin{array}{l}0.0397^{*} \\
(4.724)\end{array}$ & $\begin{array}{l}0.038^{*} \\
(5.009)\end{array}$ & $\begin{array}{l}0.05802^{*} \\
(8.276)\end{array}$ \\
\hline ADV INT & $\begin{array}{l}-0.029 \\
(-0.3953)\end{array}$ & $\begin{array}{l}0.0326 \\
(0.4009)\end{array}$ & $\begin{array}{l}0.0387 \\
(0.4483)\end{array}$ & $\begin{array}{l}0.293^{*} \\
(3.613)\end{array}$ \\
\hline HOSTILE & $\begin{array}{l}0.46435 \\
(1.49)\end{array}$ & $\begin{array}{l}0.4504 \\
(1.427)\end{array}$ & $\begin{array}{l}0.8849 * \\
(4.188)\end{array}$ & $\begin{array}{l}0.9142 * \\
(5.617)\end{array}$ \\
\hline FOR.SALES & & & $\begin{array}{l}-0.8527 * * \\
(-2.166)\end{array}$ & $\begin{array}{l}-0.0814 \\
(-0.2088)\end{array}$ \\
\hline$\underset{\text { SAMPLE SIZE }}{\text { ADJUSTED }} \mathbf{R}^{2}$ & $\begin{array}{l}0.0125 \\
317\end{array}$ & $\begin{array}{l}0.0343 \\
185\end{array}$ & $\begin{array}{l}0.0493 \\
220\end{array}$ & $\begin{array}{l}0.2028 \\
120\end{array}$ \\
\hline
\end{tabular}

Numbers in parantheses are p-values. * represents significance at the 1 per cent level, ** represents significance at the 5 per cent level and $* * *$ represents significance at the 10 per cent level. 